\title{
Computed tomography use in minor head injury: attitudes and practices of emergency physicians, neurosurgeons, and radiologists in Turkey
}

\author{
Ebru Özan, M.D., Gökçe Kaan Ataç, M.D. \\ Department of Radiology, Ufuk University Faculty of Medicine, Ankara-Turkey
}

\begin{abstract}
BACKGROUND: We aimed to determine the attitudes and practices of emergency physicians (EPs), neurosurgeons, and radiologists in Turkey regarding computed tomography (CT) use for adults with minor head injury (MHI).

METHODS: This cross-sectional study was conducted between August 2015 and October 2016 after obtaining the approval of the institutional ethical committee. The purpose of this study was disclosed to the participants prior to beginning the survey. The study was performed conducting a questionnaire via e-mail on three groups of participants including EPs, neurosurgeons, and radiologists. Participants comprised academic staff at university hospitals as well as department chiefs, specialists, and residents working at university, government, and private hospitals, all of whom are in charge of evaluating MHI patients.
\end{abstract}

RESULTS: A total of 607 participants including 20 I (33.1\%) EPs, I 79 (29.5\%) neurosurgeons, and 227 (37.4\%) radiologists responded to the survey; $31 \%$ of the participants reported awareness and $27.3 \%$ reported use of head CT rules in MHI. Awareness and use of the rules were most prominent in EPs group, while the lowest rates were observed in radiologists group $(p<0.0 \mathrm{I})$. The leading factors inhibiting the use of head CT rules in $\mathrm{MHI}$ stated by EPs were medicolegal anxiety $(73.6 \%)$, expectations of patients and/or patient relatives (72.6\%), and time constraints (44.3\%). The leading factors stated by neurosurgeons were medicolegal anxiety $(60.9 \%)$ and expectations of patient and/or patient relatives (46.4\%); "not being consulted in the decision-making process to obtain CT in MHI" (65.6\%) and medicolegal anxiety $(49.8 \%)$ were the leading factors stated by radiologists.

CONCLUSION: The results of our study show that many physicians in Turkey do not have favorable attitudes regarding head CT rules in MHI. Medicolegal anxiety, expectations of patient and/or patient relatives, time constraints, wide availability of CT, and lack of adequate education on radiation protection or on patient dose from imaging are the common reasons for this practice pattern.

Keywords: Adult; appropriate use of computed tomography; head computed tomography rules; minor head injury.

\section{INTRODUCTION}

Imaging guidelines may help clinicians decide the most appropriate imaging modality and provide standardization of the imaging strategies. Increasing use of computed tomography (CT) in various countries worldwide, particularly at a higher rate in the emergency department (ED) than in other settings, has been well established. ${ }^{[1-3]}$ To minimize $\mathrm{CT}$ radiation risk and to provide more economically effective utilization of $\mathrm{CT}$, clinical decision rules have been developed. The Canadian CT
Head Rule (CCHR) and New Orleans Criteria (NOC) represent the most notable examples that were developed to correctly identify the adult patients with minor head injury $(\mathrm{MHI})$ who are at elevated risk of intracranial injury or injury requiring neurosurgical interventions. ${ }^{[4,5]}$ The use of clinical decision rules could safely reduce $\mathrm{CT}$ imaging in $\mathrm{MHI}$ and, thus, provide adherence to the justification principle of radiation protection.

Despite the availability of validated clinical decision rules in $\mathrm{MHI}$, variabilities in the awareness and use of these rules were

\footnotetext{
Cite this article as: Özan E, M.D., Ataç GK. Computed tomography use in minor head injury: attitudes and practices of emergency physicians, neurosurgeons, and radiologists in Turkey. Ulus Travma Acil Cerrahi Derg 2018;24:121-128

Address for correspondence: Ebru Özan, M.D.

Mevlana Bulvarı (Konya Yolu), No: 86-88, Balgat, 06520 Ankara, Turkey

Tel: +90 312 - 2044000 E-mail: ebrusanhal@yahoo.com

Ulus Travma Acil Cerrahi Derg 2018;24(2):I2I-128 DOI: 10.5505/tites.2017.56884 Submitted: 20.12.2016 Accepted: 21.08.2017 Online: 22.08 .2017

Copyright 2018 Turkish Association of Trauma and Emergency Surgery
} 
found among different countries. ${ }^{[6-8]}$ Therefore, the purpose of this study was to determine the attitudes and practices of emergency physicians (EPs), neurosurgeons, and radiologists in Turkey regarding $\mathrm{CT}$ use for $\mathrm{MHI}$ in adults with a special emphasis on head CT rules. To the best of our knowledge, this is the first national survey to investigate the attitudes regarding $\mathrm{CT}$ use for $\mathrm{MHI}$, as well as the awareness of head $\mathrm{CT}$ rules for $\mathrm{MHI}$ in our country. Furthermore, our approach of including different groups of physicians, all of whom are in charge of evaluating $\mathrm{MHI}$ cases, was novel and allowed us to obtain considerable results.

\section{MATERIALS AND METHODS}

This cross-sectional study was conducted between August 2015 and October 2016 after obtaining the approval of the institutional ethical committee. The purpose of this study was disclosed to the participants prior to beginning the survey.

The study was performed conducting a questionnaire via email on three groups of participants including EPs, neurosurgeons, and radiologists. Participants comprised academic staff at university hospitals as well as department chiefs, specialists, and residents working at university, government, and private hospitals, all of whom are in charge of evaluating MHI patients. We refer to all as "EPs," "neurosurgeons," and "radiologists."

\section{Data Collection}

The questionnaires were conducted using links to an online survey system (http://www.surveey.com/) that were presented via e-mails. Neurosurgeons and radiologists were e-mailed through their national societies, while EPs were emailed through personel contacts. After providing consent, participants completed the survey online. Those who did not respond were e-mailed two more times.

The questionnaire was multiple-choice; besides, some questions that the participants could answer by choosing more than one answer were also included. The survey was designed so that the participants could not proceed to the next question without answering the previous one. Exceptionally, the last question allowed the participants to optionally mention their comments and suggestions. The questionnaire was divided into four main sections. In the first section, participants were asked about their demographic information, employment organizations, and positions. The second section assessed the frequency of head injury $(\mathrm{HI})$ cases, the physician who decides whether or not to obtain CT in MHI cases, and the availability of CT at participants' institutions. In the third section, the participants were asked about their educational status on radiation protection. In addition, their knowledge about the radiation dose administered during a head CT was assessed by asking them simply to compare the effective dose of a head CT to anteroposterior (AP) and lateral skull radiographs. Choices for this question were as follows: a) Roughly the same, b) 10-50 fold, c) 50-100 fold, d) 100-500 fold, e)
Survey of CT use in minor head injury, sample survey form

I. Demographics

I. Current hospital you are working at:

a. University hospital

b. Education and research hospital

c. State hospital

d. Private practice

2. Your position:

a. Head/chief of department

b. Teaching staff

c. Specialist

d. Resident

II. Approximate number of head injury cases, physician to decide whether or not to obtain CT in MHI cases, availability of CT

I. App. number of $\mathrm{HI}$ cases in your institution:

a. $<100$

b. $100-500$

c. $500-100$

d. $>1000$

2. Physician to decide whether or not to obtain $\mathrm{CT}$ in $\mathrm{HI}$ cases in your institution:

a. EPs

b. Neurosurgeons

c. Radiologist

d. Agreed decision

3. Availability of $\mathrm{CT}$ in your institution

a. No

b. Yes, during working hours

c. Yes, 24 hours a day

III. Edicational status on radiation protection, knowledge about the radiation dose

I. Have you ever received any formal education on radiation protection? a. Yes

b. No

2. Radiation dose (effective dose, milisievert) administered during a head CT in comparison to anteroposterior (AP) and lateral skull radiographs is:

a. Roughly the same

b. $10-50$ fold

c. $50-100$ fold

d. $100-500$ fold

e. I do not know

IV. Awareness and use of head CT rules in MHI, main factors to inhibit the use of these rules

I. Your knowledge level on head $\mathrm{CT}$ rules in $\mathrm{MHI}$

a. Absent

b. Insufficient

c. Sufficient

2. How often do you use head $\mathrm{CT}$ rules in $\mathrm{MH}$ ?

a. Never

b. Sometimes

c. Mostly

d. Always

3. The main factors for you to inhibit the use of head CT rules in (you may choose one to five statements):

a. I adhere to a head CT rule effectively

b. I don't know tne radiation dose administered during a head CT

c. Medico legal anxiety

d. Administrational ond/or institutional pressure to order imaging examinations

e. Expectations of patient and/or patient relatives about the obtainment of a head CT

f. Lack of other imaging modality in my institution

g. Time constraints due to work overload

h. Nobody ask and/or cares about my opinion on obtaining head CT in MHI cases

i. Diagnostic information provided by head CT in MHI cases is more important than the radiation exposure, unnecessary costs or work overload

v. Please mention any of your comments and suggestions regarding $\mathrm{CT}$ use in $\mathrm{MHI}$ and/or radiation protection...

Figure 1. Survey of CT use in minor head injury, sample survey form. EPs, emergency physicians; App.: Approximate; HI: Head injury; CT: Computed tomography; MHI: Minor head injury. 
Do not know. Typical effective doses per procedure for a head $\mathrm{CT}$, an AP skull radiography, and a lateral skull radiography are 2, 0.03, and 0.01 mSv, respectively (https://hps.org/physicians/ documents/Doses_from_Medical_X-Ray_Procedures.pdf). Thus, the correct answer for this question was 10-50 fold (choice b). Choice a was accepted as "underestimation" and choices c and d were accepted as "overestimation" regarding this question. In the fourth section, participants were asked three questions to assess their practices on ordering $C T$ in $\mathrm{MHI}$, awarenesses and attitudes regarding head $\mathrm{CT}$ rules in $\mathrm{MHI}$, and the main factors that inhibit the use of these rules. The last section of the survey asked participants about their comments and suggestions on $\mathrm{CT}$ use in $\mathrm{MHI}$ and/or radiation protection, if any. A sample survey form that contains the questions and choices is shown in Fig. I.

\section{Statistical Analysis}

Analysis of the results was performed using the IBM SPSS Statistics Version 21.0 software for Windows (Armonk, NY). For descriptive analysis, means, standard deviations, and frequency tables were used. To investigate differences between the groups, Mann-Whitney U-test was used for two groups and Kruskal-Wallis $\mathrm{H}$ test for more than two groups. $\mathrm{X}^{2}$ test was performed for categorical variables. Significance was defined as $\mathrm{p}<0.05$.

\section{RESULTS}

A total of 607 participants including 201 (33.1\%) EPs, 179 (29.5\%) neurosurgeons, and 227 (37.4\%) radiologists responded to the survey.

\section{First Section: Demographics}

Of the 607 participants, $32.9 \%$ worked in university hospitals, $26.2 \%$ in education and research hospitals, $23.1 \%$ in state hospitals, and $17.8 \%$ in private practice. Specialists comprised
$55.5 \%$ of the participants. Employment organizations and positions of the participants are presented in Table I.

\section{Second Section: Approximate Number of HI}

Cases, Physician who Decides Whether or Not to Obtain CT in MHI Cases, and Availability of CT

The most reported (37.2\%) approximate number of head trauma cases per month at participants' institutions was 100-500. When the participants were asked which physician at their institution decides whether or not to obtain CT in $\mathrm{MHI}$ cases; the majority (79.9\%) responded "EPs"; $93.4 \%$ of the participants stated that CT is available $24 \mathrm{~h}$ a day at their institutions. Table 2 presents the responses given by each participant group regarding the questions included in the second section of the survey.

\section{Third Section: Educational Status on Radiation Protection and Knowledge About the Radiation Dose}

Of all the particpants, $42.3 \%$ stated that they have received formal education (course, congress, symposium, lecture, etc.) on radiation dose from medical imaging or on radiation protection, while $57.7 \%$ stated that they have not. Regarding a question on the radiation dose administered during a head CT, $25.4 \%$ of the participants gave the correct answer, $58.3 \%$ of underestimated the radiation dose, $3.8 \%$ overestimated the radiation dose, and $12.5 \%$ responded "do not know." The distribution of the answers in each participant group regarding these two questions is presented in Table 3.

\section{Fourth Section: Awareness and Use of Head CT Rules in MHI and Main Factors Inhibiting the Use of These Rules}

When the participants were asked about their knowledge level on head CT rules in MHI, $35.7 \%$ of the participants re-

Table I. Employment organizations and positions of each participant groups

\begin{tabular}{|c|c|c|c|c|c|c|c|c|}
\hline & \multicolumn{2}{|c|}{ EPs } & \multicolumn{2}{|c|}{ Neurosurgeons } & \multicolumn{2}{|c|}{ Radiologists } & \multicolumn{2}{|c|}{ Total } \\
\hline & $\mathbf{n}$ & $\%$ & $\mathbf{n}$ & $\%$ & $\mathbf{n}$ & $\%$ & $\mathbf{n}$ & $\%$ \\
\hline \multicolumn{9}{|l|}{ Employment organizations } \\
\hline University hospitals & 77 & 38.3 & 44 & 24.6 & 79 & 34.8 & 200 & 32.9 \\
\hline Education and research hospitals & 69 & 34.3 & 36 & 20.1 & 54 & 23.8 & 159 & 26.2 \\
\hline State hospitals & 38 & 18.9 & 45 & 25.1 & 57 & 25.1 & 140 & 23.1 \\
\hline Private practice & 17 & 8.5 & 54 & 30.2 & 37 & 16.3 & 108 & 17.8 \\
\hline \multicolumn{9}{|l|}{ Positions } \\
\hline Head / chief of department & 10 & 5 & 15 & 8.4 & 5 & 2.2 & 30 & 4.9 \\
\hline Teaching staff & 34 & 16.9 & 48 & 26.8 & 38 & 16.7 & 120 & 19.8 \\
\hline Specialist & 90 & 44.8 & 110 & 61.5 & 137 & 60.4 & 337 & 55.5 \\
\hline Resident & 67 & 33.3 & 6 & 3.4 & 47 & 20.7 & 120 & 19.8 \\
\hline
\end{tabular}

EPs: Emergency physicians. 
Table 2. Distribution of the responses given by each participant group regarding the questions included in the second section of the survey

\begin{tabular}{|c|c|c|c|c|c|c|c|c|}
\hline & \multicolumn{2}{|c|}{ EPs } & \multicolumn{2}{|c|}{ Neurosurgeons } & \multicolumn{2}{|c|}{ Radiologists } & \multicolumn{2}{|c|}{ Total } \\
\hline & $\mathbf{n}$ & $\%$ & $\mathbf{n}$ & $\%$ & $\mathbf{n}$ & $\%$ & $\mathbf{n}$ & $\%$ \\
\hline \multicolumn{9}{|l|}{ App. No. of $\mathrm{HI}$ cases } \\
\hline$<100$ & 44 & 21.9 & 89 & 49.7 & 63 & 27.8 & 196 & 32.3 \\
\hline $100-500$ & 89 & 44.3 & 62 & 34.6 & 75 & 33 & 226 & 37.2 \\
\hline $500-1000$ & $4 I$ & 20.4 & 19 & 10.6 & 54 & 23.8 & 114 & 18.8 \\
\hline$>1000$ & 27 & 13.4 & 9 & 5.0 & 35 & 15.4 & 71 & 11.7 \\
\hline \multicolumn{9}{|l|}{ Physician who decides whether } \\
\hline \multicolumn{9}{|l|}{ or not to obtain $\mathrm{CT}$ in $\mathrm{MHI}$ cases } \\
\hline EPs & 184 & 91.5 & 105 & 58.7 & 196 & 86.3 & 485 & 79.9 \\
\hline Neurosurgeons & 6 & 3 & 53 & 29.6 & 15 & 6.6 & 74 & 12.2 \\
\hline Radiologists & 0 & 0 & 1 & 0.6 & 2 & 0.9 & 3 & 0.5 \\
\hline Agreed decision & II & 5.5 & 20 & 11.2 & 14 & 6.2 & 45 & 7.4 \\
\hline \multicolumn{9}{|l|}{ Availability of CT } \\
\hline No & 3 & 1.5 & 2 & I.I & 14 & 6.2 & 19 & 3.1 \\
\hline Yes. during working hours & 4 & 2 & 2 & I.I & 15 & 6.6 & 21 & 3.5 \\
\hline Yes. 24 h a day & 194 & 96.5 & 175 & 97.8 & 198 & 87.2 & 567 & 93.4 \\
\hline
\end{tabular}

App.: Approximate; HI: Head injury; CT: Computed tomography; EPs: Emergency physicians.

Table 3. Distribution of the answers in each participant group regarding the questions included in the third section of the survey

\begin{tabular}{|c|c|c|c|c|c|c|c|}
\hline \multicolumn{2}{|c|}{ EPs } & \multicolumn{2}{|c|}{ Neurosurgeons } & \multicolumn{2}{|c|}{ Radiologists } & \multicolumn{2}{|c|}{ Total } \\
\hline $\mathbf{n}$ & $\%$ & $\mathbf{n}$ & $\%$ & $\mathbf{n}$ & $\%$ & $\mathbf{n}$ & $\%$ \\
\hline
\end{tabular}

\begin{tabular}{|c|c|c|c|c|c|c|c|c|}
\hline \multicolumn{9}{|l|}{$\begin{array}{l}\text { Formal education on } \\
\text { radiation protection }\end{array}$} \\
\hline Yes & 45 & 22.4 & 44 & 24.6 & 168 & 74 & 257 & 42.3 \\
\hline No & 156 & 77.6 & 135 & 75.4 & 59 & 26 & 350 & 57.7 \\
\hline \multicolumn{9}{|l|}{ Radiation dose administered } \\
\hline \multicolumn{9}{|l|}{ during a head CT } \\
\hline Responded correctly & 47 & 23.4 & 30 & 16.8 & 77 & 33.9 & 154 & 25.4 \\
\hline Underestimated & 128 & 63.7 & 97 & 54.2 & 129 & 56.8 & 354 & 58.3 \\
\hline Overestimated & 5 & 2.5 & 12 & 6.7 & 6 & 2.6 & 23 & 3.8 \\
\hline Responded "Do not know" & 21 & 10.4 & 40 & 22.3 & 15 & 6.6 & 76 & 12.5 \\
\hline
\end{tabular}

CT: Computed tomography; EPs: Emergency physicians.

sponded "absent," 33.2\% responded "insufficient," and 31.1\% responded "sufficient." Majority (59\%) of the radiologists and (36.9\%) neurosurgeons responded "absent," while majority $(60.8 \%)$ of EPs responded "sufficient" regarding this question. Percantage distribution of the responses regarding this question in each participant group is presented in Figure 2.

When the participants were asked how often they use head CT rules in MHI, $6.9 \%$ responded "always," $20.4 \%$ responded "mostly," 22.4\% responded "sometimes," and 50.2\% responded "never." Majority (43.3\%) of EPs responded "mostly," while majority (51.4\%) of the neurosurgeons and $(79.7 \%)$ radiologists responded "never." Percantage distribution of the responses regarding this question in each participant group is presented in Figure 3.

The third question in the fourth section asked about the main factors inhibiting the use of head CT rules in MHI. The first 


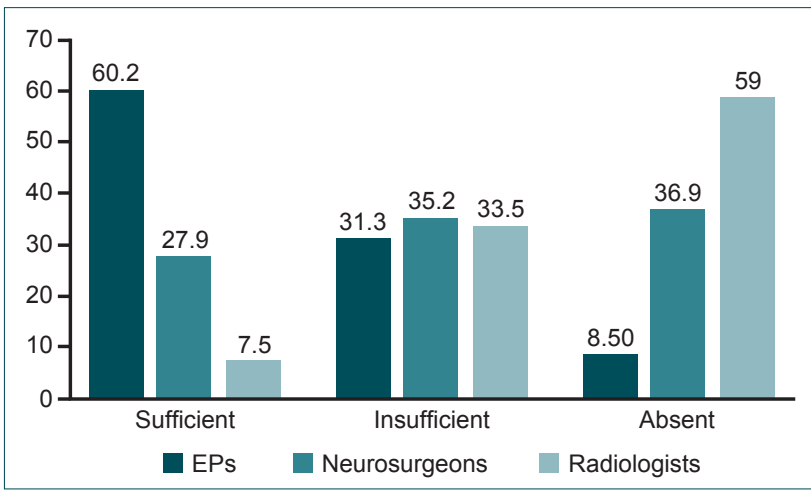

Figure 2. Percantage distribution of the responses in each participant group regarding their knowledge level on head CT rules in minor head injury.

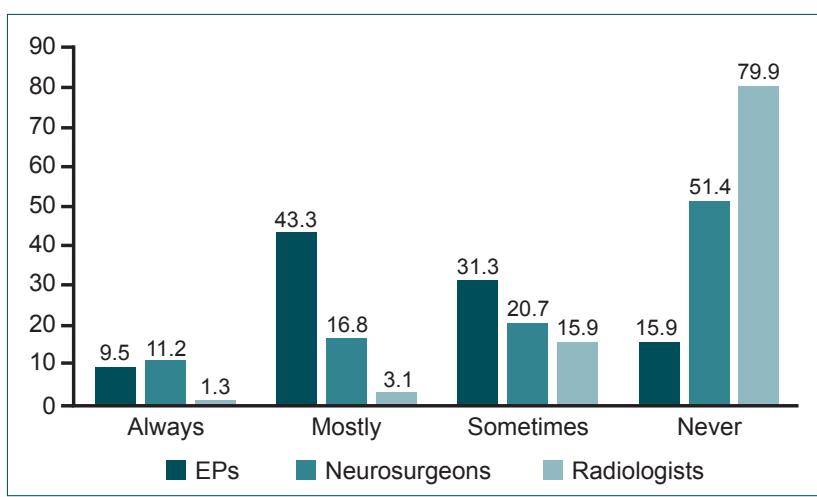

Figure 3. Percantage distribution of the responses in each participant group regarding the frequency of usage of head CT rules in minor head injury.

choice was "I adhere to a head CT rule efficiently," while the remaining eight choices mentioned possible factors inhibiting the use of rules. The respondents could choose more than

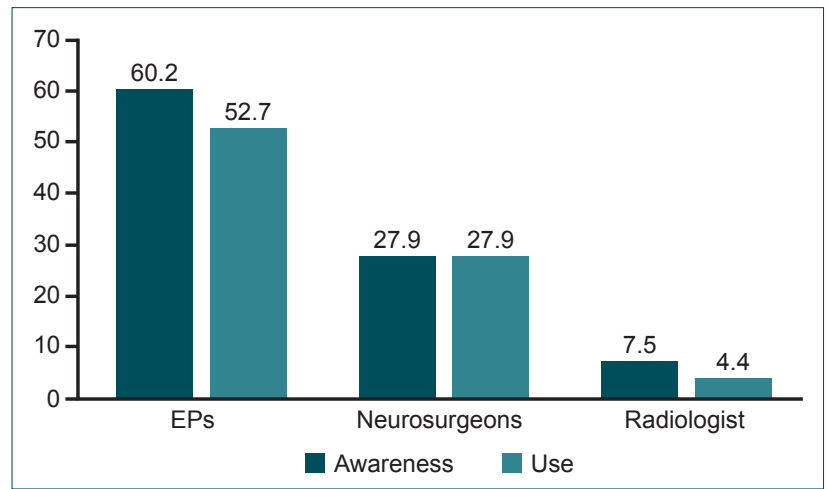

Figure 4. Percantage of the respondents in each group who reported awareness and use of head CT rules in minor head injury.

one statement without exceeding five. Responses regarding each of the possible factors were separately evaluated; $16.9 \%$ of EPs, $16.2 \%$ of the neurosurgeons, and $2.6 \%$ of the radiologists stated that they adhere to a head CT rule efficiently. The leading factors inhibiting the use of head $\mathrm{CT}$ rules in $\mathrm{MHI}$ stated by EPs were medicolegal anxiety (73.6\%), expectations of patients and/or patient relatives $(72.6 \%)$, and time constraints $(44.3 \%)$. The leading factors stated by neurosurgeons were medicolegal anxiety $(60.9 \%)$ and expectations of patient and/or patient relatives (46.4\%); "not being consulted in the decision-making process to obtain CT in MHI" (65.6\%) and medicolegal anxiety $(49.8 \%)$ were the most rated factors by radiologists. The distribution of the responses regarding the factors inhibiting the use of head $\mathrm{CT}$ rules in $\mathrm{MHI}$ in each participant group is presented in Table 4.

\section{Fifth Section: Comments and Suggestions on CT Use in MHI and/or Radiation Protection}

A total of 183 responses (30.1\%) were obtained in this section.

Table 4. Distribution of the responses regarding the factors to inhibit the use of head CT rules in MHI in each participant group

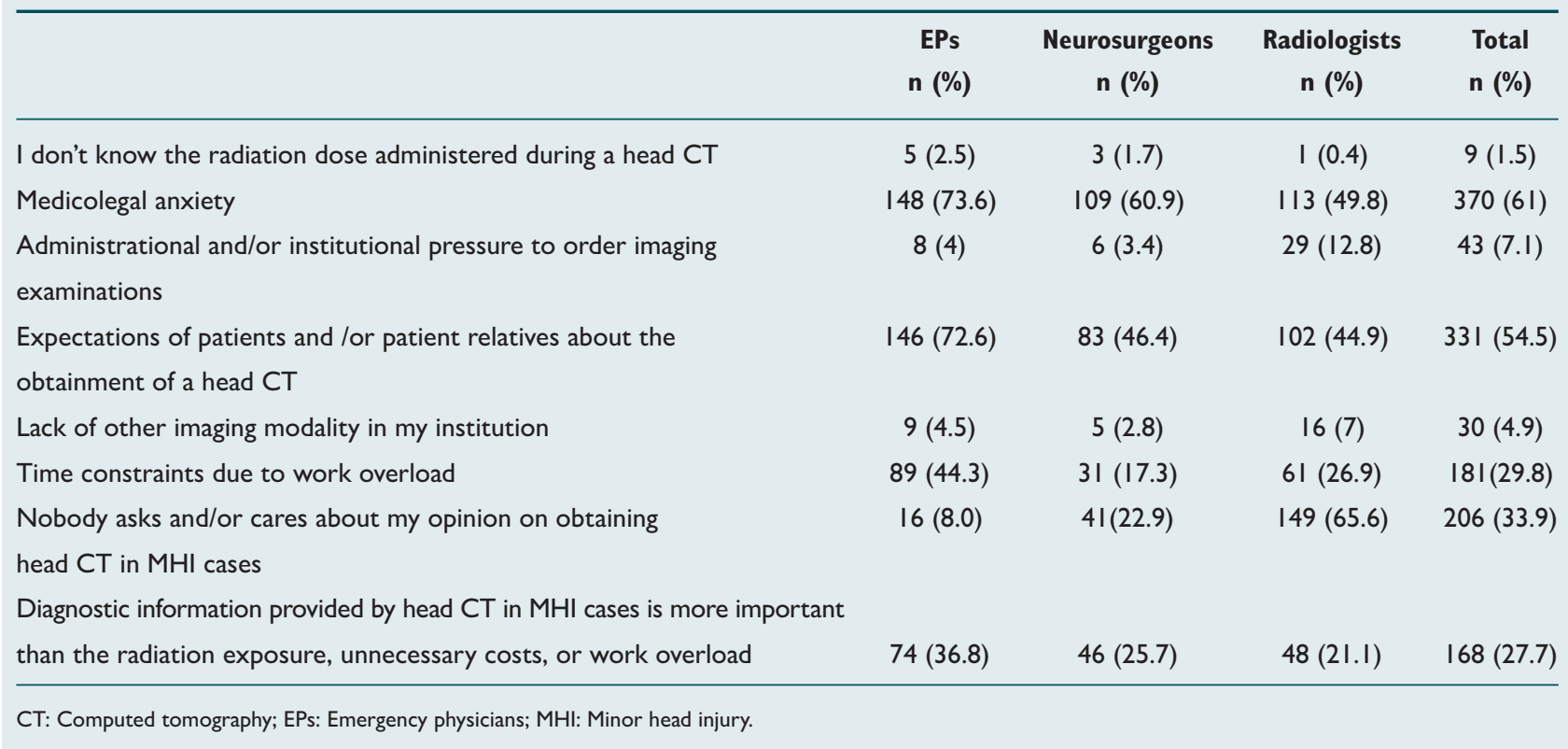


Participants most commonly pointed out medicolegal anxiety, expectations of patient and/or patient relatives, and time constraints as the factors restricting the use of the head CT rules in $\mathrm{MHI}$ in this section of the survey. The requirement for an improved medicolegal climate was commonly adressed by participants in all three groups. Radiologists and some of the neurosurgeons commonly stated that they are not involved in the decision-making process because EPs decide whether or not to obtain $\mathrm{CT}$ in $\mathrm{MHI}$ cases. Education on radiation dose from medical imaging of both the referring physicians and patients was stated as a significant factor to reduce CT overutilization in MHI. The importance of a compatible national guideline for management of $\mathrm{MHI}$ to be designated by the consensus of Ministry of Health and national medical societies of related physicians was also emphasized. Many physicians stated that they would welcome any kind of head CT rule or national imaging guideline in improved medicolegal settings.

\section{Comparison of Groups}

\section{a) Educational status on radiation protection and} knowledge about the radiation dose

When participant groups were compared in terms of their educational status on radiation protection, a significant difference was found between radiologists and the other two groups $(p<0.01)$, while no significant difference was found between EPs and neurosurgeons $(p=0.614)$. Accordingly, the number of radiologists who had received formal education on radiation dose from medical imaging or on radiation protection was more prominent than EPs and neurosurgeons. When three groups were compared regarding their knowledge about the radiation dose administered during a head $\mathrm{CT}$, no significant difference was found between EPs and radiologists $(p=0.079)$, while the differences between EPs and neurosurgeons as well as neurosurgeons and radiologists were found to be significant $(p<0.01$ and $p<0.01$, respectively). Accordingly, the number of neurosurgeons who stated that they do not know the radiation dose administered during a head CT was more prominent than EPs and radiologists, while the correct answer rate of radiologists was higher than the neurosurgeons.

\section{b) Awareness and use of head CT rules in $\mathrm{MHI}$}

To compare the groups, we considered "sufficient" knowledge level on head CT rules in MHI as "awareness"; furthermore, we considered respondents who reported that they use the rules "always" or "mostly" as users and those who reported that they use the rules "sometimes" or "never" as nonusers. Accordingly, $31 \%$ of the participants reported awareness and $27.3 \%$ reported use of head CT rules in $\mathrm{MHI}$. A significant difference was found between the groups regarding the awareness and use of the rules $(p<0.01$ and $p<0.01$, respectively). Awareness and use of the rules were most prominent in EPs group, while the lowest rates were observed in radiologists group. Percantage of the respondents in each group who reported awareness and use of head $\mathrm{CT}$ rules in $\mathrm{MHI}$ is presented in Figure 4.

\section{DISCUSSION}

$\mathrm{HI}$ accounts for a significant part of ED attendances; most of these are MHls (Glasgow Coma Scale score, 13-15), with an annual incidence estimated to be 100-600 per 100,000 in the general population. ${ }^{[9,10]}$ Head CT is the standard imaging modality in acute $\mathrm{HI}$; it is increasingly being performed routinely in patients with $\mathrm{MHI}$, although the incidence of clinically significant findings on head CT is reported to be $5 \%-9 \%$ with less than $1 \%$ of these requiring neurosurgical interventions. ${ }^{[1-14]} \mathrm{CT}$ overutilization, particularly at a higher rate in EDs, has been well established. ${ }^{[15-17]}$ This overutilization consequently led to concerns about $\mathrm{CT}$ radiation risk and increasing health care costs. Thus, appropriate use of CT has become an issue, and efforts to decrease overutilization put clinical decision rules forward. CCHR and NOC represent the most sensitive and specific head CT rules at identifying clinically important intracranial lesions in adult patients with MHI. ${ }^{[1,19]}$ Although the implementation of head CT rules, CCHR specifically, has the potential to increase $\mathrm{CT}$ use in $\mathrm{MHI}$ by $35 \%$, substantial variations among countries regarding $\mathrm{CT}$ use in $\mathrm{MHI}$, as well as awareness and the use of head CT rules have been established. ${ }^{\left[{ }^{20-22]}\right.} \mathrm{High}$ frequency of noncompliance with guidelines even after intensive implementation efforts has also been reported. ${ }^{[8]}$

This is the first national survey specifically aimed at identifying the attitudes and practices regarding $\mathrm{CT}$ use in adult patients with MHI. Three groups of participants including EPs, neurosurgeons, and radiologists, all of whom are in charge of evaluating $\mathrm{MHI}$ cases in our country were included. We found that overall awareness and use of head CT rules in our country were relatively low compared with other countries, as reported by some studies. An international survey of EPs showed that awareness and use of CCHR were highest ( $86 \%$ and $57 \%$, respectively) in Canada and lowest $(31 \%$ and $12 \%$, respectively) in the United States. ${ }^{[7]}$ Heskestad et al. ${ }^{[8]}$ reported a $51 \%$ overall physicians compliance after the national implementation process of the Scandinavian Guidelines for initial management of minimal, mild, and moderate Hls.

Our study revealed that EPs are the physicians who mainly decide whether to obtain CT or not in $\mathrm{MHI}$ in our country. Therefore, we must point out that while overall awareness and use of head CT rules were found to be low in our study, the highest rates were reported by EPs, $60.2 \%$ and $52.7 \%$ respectively. Awareness and use of the rules were found to be lower in neurosurgeons. Management of $\mathrm{MHI}$ cases, especially those where no neurosurgical interventions are required, seems to be handled mainly by EPs, and head CTs are mainly being ordered depending on EPs' decisions. Notably, lower rates reported by neurosurgeons may somewhat be reasonable.

However, lowest rates of awareness and use of head CT rules reported by radiologists can not be explained solely on the basis of the abovementioned management and CT ordering practice in $\mathrm{MHI}$ in our country. Moreover, the most rated 
factor restricting the use of head CT rules in MHI stated by radiologists was "not being consulted in the decision-making process to obtain CT in MHI." While justification is one of the three fundamental principles of radiation protection, radiologists, as masters of the radiation enviroment, have the responsibility of being proactive in this area instead of remaining in the background. ${ }^{[23,24]}$

Although there is no reliable data regarding the rate of $\mathrm{CT}$ use in $\mathrm{MHI}$ cases in our country, the reported awareness and use rates of the rules as well as the statements in the comments and suggestions section of this survey led us to conclude that most referring physicians do not have favorable attitudes regarding head CT rules in MHI. Given the wide availability of CT $(93.4 \%$ of the participants stated that CT is available $24 \mathrm{~h}$ a day at their institutions), increasing physician pressure related to both medicolegal issues and expectations of patients and/or patient relatives, and time constraints due to work overload, some of the physicians in our country seem to welcome the nonselective $\mathrm{CT}$ use in $\mathrm{MHI}$ cases. As medicolegal anxiety, expectations of patients and/or patient relatives, and time constraints were the most rated factors, particularly by EPs, our results draw particular attention to the role of nonclinical factors in restricting the use of head CT rules, as already reported in some studies. ${ }^{[25-27]}$ Furthermore, this data may provide more insight into the defensive medicine practices of physicians in our country. Physicians' concerns about medicolegal issues and perceptions on medicolegal risk play a significant role in their patient management, and this may lead to additional imaging, particularly increased CT use. ${ }^{[28,29]}$

Most EPs and neurosurgeons stated that they had not received any kind of formal education on radiation protection. While the majority of the participants underestimated the radiation dose administered during a head CT, a greater percentage of radiologists provided a correct estimation than EPs and neurosurgeons. The tendency to underestimate the radiation dose administered during a head CT may partially be explained based on the lack of sufficient education and may lead to unnecessary CT utilization in $\mathrm{MHI}$ cases. Therefore, we believe that requirement of referring physician education on radiation protection is a remarkable implication of our study.

There are several limitations to our study. First, a survey of physicians may not necessarily reflect the actual practice patterns. It has been shown that self-reported guideline adherence rates exceed objective rates, and self-reported measures are subject to response bias. ${ }^{[30]}$ However, the primary goal of our study was to get information on physicians attitudes regarding $\mathrm{CT}$ use in $\mathrm{MHI}$, not to measure adherence to guidelines, as currently, neither a national guideline nor an implementation process exist in our country. Additionally, advocating the use of any head CT rules was also not intended in this study. Second, this survey provides information on at- titudes and practices at a single point in time; longitudinal surveys would be useful to determine the alterations.

In conclusion, we believe this study provides valuable information on CT use in MHI and physicians' attitudes regarding head $\mathrm{CT}$ rules in our country. It seems many physicians do not have favorable attitudes on $\mathrm{CT}$ head rules in $\mathrm{MHI}$. Medicolegal anxiety, expectations of patient and/or patient relatives, time constraints, wide availability of $\mathrm{CT}$, and the lack of adequate education on radiation protection or patient dose from imaging are defined as common reasons for this practice pattern. Thus, referring physician education on radiation protection as well as improvement of the current medicolegal climate and the physicians' working conditions (i.e., workload) are the potential solutions. As some of the participants indicated, implementation of either developed or adopted national guidelines showing the appropriate imaging algorithm that includes possible radiation doses for common clinical scenarios may help all stakeholders to share similar strategies for patients. Beyond these, we believe that radiologists should be encouraged to involve themselves rather than being disregarded in the decision-making process to obtain $\mathrm{CT}$, particularly in $\mathrm{MHI}$ cases.

\section{Acknowledgements}

The authors thank the following for their much appreciated assistance: Turkish Society of Radiology, Turkish Neurosurgical Society for supporting this endeavor; Drs. Drs. Togay Evrin, Basak Yilmaz and Ismail Atik for facilitating e-mail distribution among emergency physicians.

\section{Conflict of interest: None declared.}

\section{REFERENCES}

1. Mettler FA Jr, Bhargavan M, Faulkner K, Gilley DB, Gray JE, Ibbott GS, et al. Radiologic and nuclear medicine studies in the United States and worldwide: frequency, radiation dose, and comparison with other radiation sources-1950-2007. Radiology 2009;253:520-31. [CrossRef]

2. Larson DB, Johnson LW, Schnell BM, Salisbury SR, Forman HP. National trends in CT use in the emergency department: 1995-2007. Radiology 2011;258:164-73. [CrossRef]

3. Chang JC, Lin YY, Hsu TF, Chen YC, How CK, Huang MS. Trends in computed tomography utilisation in the emergency department: A 5 year experience in an urban medical centre in northern Taiwan. Emerg Med Australas 2016;28:153-8. [CrossRef]

4. Haydel MJ, Preston CA, Mills TJ, Luber S, Blaudeau E, DeBlieux PM. Indications for computed tomography in patients with minor head injury. N Engl J Med 2000;343:100-5. [CrossRef]

5. Stiell IG, Wells GA, Vandemheen K, Clement C, Lesiuk H, Laupacis A, et al. The Canadian CT Head Rule for patients with minor head injury. Lancet 2001;357:1391-6. [CrossRef]

6. Stiell IG, Wells GA, Vandemheen K, Laupacis A, Brison R, Eisenhauer MA, et al. Variation in ED use of computed tomography for patients with minor head injury. Ann Emerg Med 1997;30:14-22. [CrossRef]

7. Eagles D, Stiell IG, Clement CM, Brehaut J, Taljaard M, Kelly AM, et al. International survey of emergency physicians' awareness and use of the 
Canadian Cervical-Spine Rule and the Canadian Computed Tomography Head Rule. Acad Emerg Med 2008;15:1256-61. [CrossRef]

8. Heskestad B, Baardsen R, Helseth E, Ingebrigtsen T. Guideline compliance in management of minimal, mild, and moderate head injury: high frequency of noncompliance among individual physicians despite strong guideline support from clinical leaders. J Trauma 2008;65:1309-13.

9. Cassidy JD, Carroll LJ, Peloso PM, Borg J, von Holst H, Holm L, et al. Incidence, risk factors and prevention of mild traumatic brain injury: results of the WHO Collaborating Centre Task Force on Mild Traumatic Brain Injury. J Rehabil Med 2004:28-60. [CrossRef]

10. Pandor A, Goodacre S, Harnan S, Holmes M, Pickering A, Fitzgerald P, et al. Diagnostic management strategies for adults and children with minor head injury: a systematic review and an economic evaluation. Health Technol Assess 2011;15:1-202. [CrossRef]

11. Miller EC, Derlet RW, Kinser D. Minor head trauma: Is computed tomography always necessary? Ann Emerg Med 1996;27:290-4. [CrossRef]

12. Haydel MJ, Preston CA, Mills TJ, Luber S, Blaudeau E, DeBlieux PM. Indications for computed tomography in patients with minor head injury. N Engl J Med 2000;343:100-5. [CrossRef]

13. Stiell IG, Clement CM, Rowe BH, Schull MJ, Brison R, Cass D, et al. Comparison of the Canadian CT Head Rule and the New Orleans Criteria in patients with minor head injury. JAMA 2005;294:1511-8. [CrossRef]

14. Morton MJ, Korley FK. Head computed tomography use in the emergency department for mild traumatic brain injury: integrating evidence into practice for the resident physician. Ann Emerg Med 2012;60:361-7.

15. Boone JM, Brunberg JA. Computed tomography use in a tertiary care university hospital. J Am Coll Radiol 2008;5:132-8. [CrossRef]

16. Larson DB, Johnson LW, Schnell BM, Salisbury SR, Forman HP. National trends in CT use in the emergency department: 1995-2007. Radiology 2011;258:164-73. [CrossRef]

17. Broder J, Warshauer DM. Increasing utilization of computed tomography in the adult emergency department, 2000-2005. Emerg Radiol 2006;13:25-30. [CrossRef]

18. Harnan SE, Pickering A, Pandor A, Goodacre SW. Clinical decision rules for adults with minor head injury: a systematic review. J Trauma 2011;71:245-51. [CrossRef]
19. Papa L, Stiell IG, Clement CM, Pawlowicz A, Wolfram A, Braga C, et al. Performance of the Canadian CT Head Rule and the New Orleans Criteria for predicting any traumatic intracranial injury on computed tomography in a United States Level I trauma center. Acad Emerg Med 2012;19:2-10.

20. Melnick ER, Szlezak CM, Bentley SK, Dziura JD, Kotlyar S, Post LA. CT overuse for mild traumatic brain injury. Jt Comm J Qual Patient Saf 2012;38:483-9. [CrossRef]

21. Andruchow JE, Raja AS, Prevedello LM, Zane RD, Khorasani R. Variation in head computed tomography use for emergency department trauma patients and physician risk tolerance. Arch Intern Med 2012;172;660-1.

22. Marin JR, Shofer FS, Chang I, Mills AM. Adherence to a clinical decision policy for head computed tomography in adult mild traumatic brain injury. Am J Emerg Med 2015;33:299-300. [CrossRef]

23. ICRP Publication 105. Radiation protection in medicine. Ann ICRP 2007;37:1-63. [CrossRef]

24. Frey GD. Control and management of the radiation environment. AJR Am J Roentgenol 2010;194:867. [CrossRef]

25. Wong AC, Kowalenko T, Roahen-Harrison S, Smith B, Maio RF, Stanley RM. A survey of emergency physicians' fear of malpractice and its association with the decision to order computed tomography scans for children with minor head trauma. Pediatr Emerg Care 2011;27:182-5.

26. Melnick ER, Shafer K, Rodulfo N, Shi J, Hess EP, Wears RL, et al. Understanding Overuse of Computed Tomography for Minor Head Injury in the Emergency Department: A Triangulated Qualitative Study. Acad Emerg Med 2015;22:1474-83. [CrossRef]

27. Rohacek M, Albrecht M, Kleim B, Zimmermann H, Exadaktylos A. Reasons for ordering computed tomography scans of the head in patients with minor brain injury. Injury 2012;43:1415-8. [CrossRef]

28. Katz DA, Williams GC, Brown RL, Aufderheide TP, Bogner M, Rahko PS, et al. Emergency physicians' fear of malpractice in evaluating patients with possible acute cardiac ischemia. Ann Emerg Med 2005;46:525-33.

29. Solaroglu I, Izci Y, Yeter HG, Metin MM, Keles GE. Health transformation project and defensive medicine practice among neurosurgeons in Turkey. PLoS One 2014;9:e111446. [CrossRef]

30. Adams AS, Soumerai SB, Lomas J, Ross-Degnan D. Evidence of selfreport bias in assessing adherence to guidelines. Int J Qual Health Care 1999;11:187-92. [CrossRef]

\section{ORİJINAL ÇALIŞMA - ÖZET}

\section{Minör kafa travmasında bilgisayarlı tomografi kullanımı: Türkiye'deki acil tıp hekimleri, beyin cerrahları ve radyologlarin tutum ve uygulamaları}

\section{Dr. Ebru Özan, Dr. Gökçe Kaan Ataç}

Ufuk Üniversitesi Tıp Fakültesi, Radyoloji Anabilim Dalı, Ankara

AMAÇ: Türkiye'deki acil tıp hekimleri, beyin cerrahları ve radyologların, minör kafa travmasında (MKT) bilgisayarlı tomografi (BT) kullanımı ile ilgili tutum ve davranışlarını belirlemektir.

GEREÇ VE YÖNTEM: Çalışma acil tıp hekimleri, beyin cerrahları ve radyologlara anket formu uygulanarak gerçekleştirildi.

BULGULAR: Ankete $20 \mathrm{I}$ acil tıp hekimi, 179 beyin cerrahı ve 227 radyolog dahil olmak üzere toplam 607 katılımcı yanıt verdi. Minör kafa travmasında beyin BT kuralları ile ilgili genel farkındalık oranı \%3। olarak bulundu. Katılımcıların \%27.3'ü kuralları uyguladığını bildirdi. Kuralların farkındalığı ve kullanımı acil tıp hekimi grubunda en belirgin iken en düşük oranlar radyologlar grubunda gözlendi $(\mathrm{p}<0.0 \mathrm{I})$. Acil tıp hekimlerinin MKT'de beyin BT kurallarını kullanmalarını engelleyen başlıca etkenler; mediko legal kaygı (\%73.6), hastaların ve/veya hasta yakınlarının beklentileri (\%72.6) ve zaman kısıtlamaları (\%44.3) idi. Beyin cerrahlarının belirttikleri başta gelen faktörler; mediko legal kaygı (\%60.9) ve hasta ve/veya hasta yakınlarının beklentileri (\%46.4) idi. Radyologlar tarafından belirtilen başlıca etken "karar verme sürecinde danışımamaktadır" (\%65.6) idi.

TARTIŞMA: Çalışmamızın sonuçları, Türkiye'de birçok hekimin MKT'de beyin BT kuralları ile ilgili olumlu tutumları olmadığını göstermektedir. Mediko legal kaygı, hastanın ve/veya hasta yakınlarının beklentileri, zaman kısıtlamaları, BT'nin yaygınlı̆ıı ve tıbbi görüntülemede radyasyondan korunma veya hasta radyasyon dozu konularında eğitim yetersizliği bu uygulama şekli için ortak nedenler olarak tanımlanmaktadır.

Anahtar sözcükler: BT uygunluğu; beyin BT kuralları; erişkin; minör kafa travması.

Ulus Travma Acil Cerrahi Derg 2018;24(2):121-128 doi: 10.5505/tjtes.2017.56884 